\title{
BLOCKCHAIN TECHNOLOGY AS AN ORGANIZATION OF ACCOUNTING AND MANAGEMENT IN A MODERN ENTERPRISE
}

\author{
Maryna Pashkevych \\ D.Sc. (Economics), Professor, Department of Accounting and Audit, \\ Dnipro University of Technology, Dnipro, Ukraine \\ Liudmyla Bondarenko \\ Ph.D., Docent, Department of Enterprise Economy, \\ Dnipro University of Technology, Dnipro, Ukraine
}

\author{
Andrii Makurin \\ Doctoral Student Department of Finance, Analusis and Insurance \\ Kharkov State University of Food Technology and Trade, Kharkov, Ukraine \\ Irina Saukh \\ Doctor of Economics, Zhytomyr State University named after Ivan Franko, \\ Professor of Department of Economics, Management and Marketing, \\ Ukraine, Zhytomyr \\ Olena Toporkova \\ Kharkiv State University of Food Technology and Trade, \\ Kharkov, Ukraine
}

\begin{abstract}
The purpose of the work is to determine the main approaches to the organization of accounting and management in a modern enterprise. The study found that blockchain technology supports the invulnerability and independence of the interests of legal entities in relation to the influence of third parties. The introduction of blockchain technology in accounting contributes to the innovative development of the system in the enterprise during the use of cryptocurrency in payments between buyers and customers. The article presents the main risks of using virtual currency. Implementation of modern technologies for the enterprise, such as cloud storage, XBRL technology, blockchain, violates the new requirements for the presentation of business (financial) reporting data and their transfer to stakeholders. Any technology must provide confidence in the representativeness of information and trust in it. The model of carrying out operation between the enterprises by means of cryptoactive assets is offered. The types of risks from the use of certain funds are analyzed. It is
\end{abstract}


determined that with the maximum expectation of income in the short term, it is appropriate to use digital currency, if the long-term period and the company is constantly forming large receivables, it is appropriate to use traditional cash.

Key words: blockchain technology, cryptocurrency, accounting, model

Cite this Article: Maryna Pashkevych, Liudmyla Bondarenko, Andrii Makurin, Irina Saukh and Olena Toporkova, Blockchain Technology as an Organization of Accounting and Management in a Modern Enterprise. International Journal of Management, 11 (6), 2020, pp. 516-528.

http://iaeme.com/Home/issue/IJM?Volume=11\&Issue $=6$

\section{INTRODUCTION}

Nowadays, blockchain technology is gaining its popularity all over the world. Leading world countries, world financial giants, transnational corporations, governments - all of them consider the prospects of blockchain application in different spheres from the electoral register and logistics to financial technologies. In Ukraine, blockchain industry is represented by the companies in different expert spheres which interact and form the ecosystem. Formation of the community and system initiative in the development of that branch in Ukraine started in 2014 with the opening of Satoshi Square, the first Bitcoin Embassy in Ukraine and Bitcoin Foundation Ukraine with new physical location of the Blockchain Hub Kyiv (Filipova et al., 2018). Ukraine has turned to be in the list of 14 countries which are recognized as the leaders of the blockchain technology implementation. The technology is represented by the distributed database consisting of the sequence of blocks; each of them contains information from the previous one making a chain of blocks. Secure nationwide economic situation is possible due to the use of modern means to protect monetary transactions. Thus, the blockchain technology supports invulnerability and independence of the interests of legal entities as for the effect of the third parties. Implementation of blockchain technology in the accounting favours innovative development of that system at an enterprise. In this context, planning of financial flows of the contracting parties as well as their financial solvency is rather important.

\section{LITERATURE REVIEW}

Numerous papers by foreign and national scientists are devoted to the topical problems of successful combination of information technologies while drawing financial reports involving blockchain technology and defining methods of payment and settling using traditional monetary means or virtual services, i.e. Heister \& Yuthas (2020) point out that blockchain technology is developing fast being tested in numerous spheres. Unique cryptocurrency characteristics and configurations make it possible for users to conduct operations connected with anonymity and settlements. Social and material characteristics of those systems will effect the ratio and promote entry of the users which might be reliable and unpredictable. It means that certain propositions are coded along with the development and application of those systems. The authors put emphasis on the necessity to complement the system with the rating of users for defining the level of reliability during the financial transactions. Bashynska et al. (2019) study functioning of cryptocurrencies and blockchain technology, determine their specific risks, and propose a mechanism to control those risks by including special subdivisions for cryptoassets risk control in the risk management culture. Edmonds et al. (2019) have developed a simulation model of receivables in the electronic format. The model is based on the random sampling from the clients' accounts. Then the electronic register sends the clients certain bills - invoices, tax invoices, purchase orders to confirm the amount of 
accounts receivable. Such a model is expedient to be used while checking the accounts receivable to estimate the real amount and to be sure in the procedure.

Ak \& Canberk (2019) propose a conceptual model CDN, which combines new structure of the blockchain architecture, i.e. BCDN. They have determined that the main reason of the blockchain methodology use is its features of the distributed contracts and completely automated reliable flow generation. The proposed structure has made it possible to change quickly virtual instances of "surrogate servers" relative to the client request and resource possibilities. That allows using cloud services for accounting being sure in their reliability. Moreover, applying the blockchain network, the authors stress that the proposed CDN model may process uniformly the distributed inquiries with high capacity taking into consideration the status of other points of presence (PoPs). Besides, data output from the blockchain helps obtain reliable information concerning the performed operations. López-Cabarcos et al. (2020) highlight that high bitcoin capitalization results in the considerable effect on the stock exchanges and financial markets. They propose their own behavioural model to estimate the investors' behaviours and high volatility with the help of the GARCH and EGARCH models. The obtained results demonstrate that bitcoin volatility is more instable within the speculative periods experiencing its reduction during the period of equilibrium state at cryptocurrency markets. Tang et al. (2019) analyze the ethics of blockchain technology and propose a conceptual model of the blockchain ethics study. Choi \& Ozkan (2019) pay their attention to the innovative technologies (artificial intelligence, fintech, and blockchain) and their influence on the corporate strategy. Onuklu (2019) carries out critical analysis of blockchain technology. Kim \& Lee (2018) propose the methods to control political risks of blockchain technology involving such international standards as NIST and ISO. Morabito (2017) represents examples of the blockchain-based business innovations. Swan (2016) stresses that blockchain is the next-generation technology making it possible to perform much more complex and large-scale computational projects. Skvortsova et al. (2020) prove that the technologies of blockchain and cryptocurrency have enabled the intelligent contracts to enter the economic medium making those technologies rather promising. Tarasova et al. (2020) conclude that cryptocurrency is the simplest investment asset being rather risky at the same time. They propose and substantiate mathematically a model to forecast the cryptocurrency rate. Adamik \& Kosta (2019) propose a model to solve the exchange issues based on the intelligent contracts operating in the Ethereum network.

Each of the mentioned scientists has contributed in the development of science; however, scientific literature pays practically no attention to the issues of blockchain technology and use of modern monetary means in accounting.

Yefimenko (2017) states that the use of virtual currency has following risks: possible loss of means due to cyberattacks against either the user's infrastructure or objects of those currency exchange platforms. Despite the assurances that blockchain technology makes it possible to protect oneself against the unauthorized access, data protection specialists have proved many times that it is possible to misappropriate cryptocurrency through the currency markets and currency exchange processes; moreover, the problem may lie in its unreliable backing. Ukrainian Deposit Guarantee Fund does not guarantee the assets kept in cryptocurrency since it does not recognize it as the operations connected with saving, i.e. they are not considered as bank deposits. One should understand that the cryptocurrency recognition is required not only for accounting at enterprises to record those assets but also for accounting the assets in a banking sector (or some other financial one); moreover, Ukraine lacks legal certainty as for that issue. Virtual currencies are not common in trade and service outlets. They are not either currency of legal instrument of payment. Thus, entrepreneurs do not have any legal liabilities to accept payments in such currencies even if they did it before. 
There may be also certain corrupt practices due to the performance of financial operations in different jurisdictions with the dissimilar protection level for investors. As a result, meeting contract requirements may be accompanied by the unpredictable situations. In addition, high volatility of such assets is possible due to the instability, thus settlement operations with the use of virtual currencies affect considerably the balance of the contract parties' interests. Formation of the zones of secured enrichment is possible including the opportunities of shady or gray businesses due to which national innovation potential will be used mostly to move incomes out of the country.

Development of the globalized digital economy all over the world effects considerably the practice of business and fiscal accounting as well as the drawing up of the financial accounts of both EU and Ukrainian enterprises. National legislation has made the domestic recordkeepers increase their competence level in the IT sphere. To do that, it was necessary to master electronic document communication for reporting to the state bodies of Ukraine as well as digital signature and stamp, taxpayer account etc. (Osmiatchenko \& Oliinyk, 2018).

Each of the traditional stages of accounting is provided by a specific way of implementation which experiences certain changes. Those stages include: detection, estimation, generalization and accumulation of the information concerning economic activity of an enterprise. In terms of the recording of economic activity, technologies of data representation in document and information generalization have changed from simple accounting being the recording of that event to double recording when events are represented along with the reasons of their occurrence. First, that information was written on the paper registers; then the registers were adapted and transferred to the digital environment with wide use of different software. That has resulted in changing data accumulation methods; the development of XBRL technology has brought new requirements for the representation of business (financial) accounting data and their transfer to the interested parties. Approaches to ensure customers' confidence in the data reliability in the accounting documents are still topical remaining practically the same: necessity in their processing by auditors and accounting data checking irrespective of their formats (paper of digital ones).

Accounting data of current enterprises are entered in the databases which are formed in special software environment. Such a software environment may be installed locally at the accountant's workplace of on the platforms of cloud computing. Our state determines at the legislative level the tendencies of innovative changes in the accounting practice by implementing digital technology XBRL to draw up financial accounting of enterprises in the unified digital format. The mentioned changes effect the theory and methodology of the accounting records maintenance; thus, it is required to complement that process with the latest developments related to the implementation of current information technology (Kurgan, 2019).

Invention of the blockchain distributed database and corresponding technology of data operation has provoked a question concerning its use, i.e. for the purpose of accounting records and control. That technology is aimed at widening the capabilities of accounting maintenance and increasing social confidence in the accounting information. Due to that, it is quite topical to study a problem of accounting and estimation of the risk level of such operations during the settlement with the help of virtual monetary means between customers and orderers. None of the scientists paid enough attention to such a problem as the identification of related parties. Because it is not possible to identify such parties through a decentralized register. It turns out that one company will be able to influence financial decisions at another company, and this affects the financial condition of both companies. They also did not understand on the basis of what information to make a decision regarding which means of payment to use: traditional money (paper), electronic or digital. 
Objective of the paper is to study modern approaches to accounting of virtual monetary means and their use during settlements and to determine the obtained risks between consumers and orders based on a simulation model. Establish a link between the company's accounting technology, the means of payment and the risk.

\section{RESULTS}

Trends in the issuance and circulation of virtual currencies (cryptocurrencies), as well as changes in the perception of the role of central banks in terms of regulatory function in countries and other bodies in monitoring compliance in this area have significant differences. For Ukraine, the small flow of such an asset in total turnover creates significant risks to the stability of the national market. However, given the development of computer networks, a direct ban on cryptocurrencies is unlikely. This affects the transactions between legal entities and individuals when using virtual money. It is necessary to be aware of the risks of using such assets, their value and exchange rate differences on the date of signing contracts and delivery of finished products.

For example, Turkey has the largest number of cryptocurrency owners. This is since the devaluation of the Turkish lira has decreased by 40 percent. This study was conducted by ING News. Below are company statistics for countries that use cryptocurrencies as a means of payment (Table 1).

Table 1 Countries that use cryptocurrencies as a means of payment

\begin{tabular}{|l|c|c|}
\hline \multicolumn{1}{|c|}{ Country } & $\begin{array}{c}\text { Percentage of } \\
\text { cryptocurrency on the total } \\
\text { money supply, \% }\end{array}$ & $\begin{array}{c}\text { Traditional cash, } \\
\text { \% }\end{array}$ \\
\hline Luxembourg & 4 & 96 \\
\hline Italy & 8 & 92 \\
\hline Germany & 8 & 92 \\
\hline Spain & 10 & 90 \\
\hline Poland & 11 & 89 \\
\hline Romania & 12 & 88 \\
\hline Turkey & 18 & 82 \\
\hline
\end{tabular}

It is worth noting that in the United States and Austria own cryptocurrencies 57 and 70 percent, respectively. About a third (35\%) of Europeans agree that bitcoin is the future as an online currency. Slightly fewer (32\%) respondents agree that cryptocurrency is the future for investing.

The use of virtual currency carries the following risks (Efimenko, 2017):

- The possibility of losing money due to a cyber-attack on the user's infrastructure or on the objects of platforms for the exchange of such currencies. Although they claim that blockchain technology protects against unauthorized access, information security experts have repeatedly proven that it is possible to illegally seize cryptocurrency through exchanges for trading such currency and its exchange;

- Unreliable warranties. Assets held in cryptocurrency are not guaranteed in Ukraine by the Deposit Guarantee Fund of individuals, as it is not recognized as safekeeping transactions, ie they are not bank deposits. The recognition of cryptocurrency is necessary not only in the accounting of enterprises for the purpose of accounting for such assets, but also for the accounting of assets in the banking sector or in any financial sector; 
- Lack of legislative certainty in Ukraine. Virtual currencies are not common in outlets and services. They are neither a legal tender nor a currency. Therefore, entrepreneurs have no legal obligation to accept certain payments in such currencies, even if they have done so before;

- Abuses in connection with financial transactions in different jurisdictions, where there is a different level of investor protection. As a result, unforeseen situations may arise when fulfilling contractual requirements;

- High volatility of such assets is achieved due to instability, so transactions in the calculation of where virtual currencies are used significantly affect the balance of interests of the parties to the contract;

- The emergence of areas of guaranteed enrichment, including through the shadow or semi-legal business, as a result of which the national innovation potential will be used mainly to generate profits abroad. The development of a globalized digital economy around the world has a significant impact on accounting and tax practices.

Preparation of financial statements of enterprises from European countries and Ukraine. At the request of national legislation, domestic accountants had to increase their level of competence in the field of IT - technology. Because of this, it was necessary to master electronic document management for reporting to state bodies of Ukraine, digital signatures and seals, electronic office of the taxpayer and much more (Osmyatchenko \& Oliynyk, 2018).

Each of the traditional stages of accounting is provided by a certain method of implementation, which changes. Such stages include: identification, measurement, generalization and accumulation of information regarding the economic activity of the enterprise. In terms of recording a business transaction, the technology for displaying data in documents and summarizing information has changed from simple accounting, which is to record such an event to a double entry, when events are displayed together with the basis of their occurrence. From the beginning, such records were made on paper registers, over time they were adapted and transferred to a digital environment with extensive use of various software. As a result, the method of data collection has changed, and after the creation of XBRL technology, new requirements for the presentation of business (financial) reporting data and their transfer to stakeholders are violated. Approaches to providing users with confidence in the accuracy of information in reporting accounting documents remain relevant and virtually unchanged: the need for their processing by auditors, verification of accounting data, regardless of the form (paper or digital).

Credentials of modern enterprises are entered into databases, which are formed in a special software environment. Such a software environment can be installed locally, at the accountant's workplace or on "cloud" computing platforms. In our country at the legislative level identified trends in innovative changes in accounting practices through the introduction of digital technology XBRL for the preparation of financial statements of enterprises in a single digital format. These changes affect the theory and methodology of accounting, so it is necessary to fill it with developments on the realities of the implementation of modern ITtechnologies (Kurgan, 2019). With the invention of the distributed blockchain database and the corresponding data processing technology, the question arose today about its application for accounting and control purposes. This technology is designed to expand the possibilities of accounting and increase public confidence in accounting information. In this regard, it is important to study the issue of accounting, measuring the level of risk of such transactions when calculating the virtual funds between buyers and customers.

Accounting supersystem should include at least three subsystems - financial, administrative, and tax accounting. It is clear that it requires the development of absolutely 
new theory on the basis of philosophical conceptualization of the role of accounting in the society and business as a controlling service information system which may be developed only on the basis of the theory of scientific knowledge. Complex problem of generation of information in economic systems may be solved only by a new science which considers information and interests of its users as the center of knowledge while a procedure of collection and processing of the facts is being sidelined. Due to that fact, the science of accounting is called "informology" (Pushkar \& Semaniuk, 2017).

Since the developed countries have the examples of using modern monetary means (i.e. cryptocurrencies) to pay for products, works, or services, our country should join that process. For instance, there are countries which demonstrate their loyalty to cryptocurrencies for their population and government using those means along with the traditional monetary means. First of all, those countries include Estonia, the USA, Denmark, Sweden, the Netherlands, Finland, Canada, and Australia.

To reduce the information chaos at modern enterprises and level of uncertainty in the functioning of a system and fluctuation of the environment as well as to counter the destructive factors of the system development, which may retransform the order into chaos, it is required to replace traditional approaches to the accounting of transactions between consumers and orderers.

In order to understand the functioning of any system it is necessary to analyze its structural elements. For example, the existing system of cash or information flows has a centralized structure. That is especially notable in the structure dealing with the organization of money turnover at local, regional, state, and international levels. Monopoly of state or some certain establishments for the databases available nowadays in the social spheres ensures information protection and trust for those sources, from which that information has been obtained. Government controls and protects such databases connected with the data of passports, driving licenses, property rights, monetary means possessed by the bank clients, email and other telecommunication services. Moreover, it should be noted that each current Internet-transaction relies on a certain structure which the society trust more or less: when it goes about money transfer, we have to rely on the legality of banks, payment systems, or supervisory bodies controlling that sphere. It should be also mentioned when we talk about the mail service notification concerning the right/wrong delivery of our message to an addressee or information from our computer's antivirus software that the system safety is beyond the threats (Melnychenko \& Hartinger, 2016).

Users are sure that the system is reliable and nothing threats its safety until everything functions in standard mode. However, it should be stressed that the information reliability depends on its checking method and sources. For instance, banking establishments check financial soundness of physical entities and their credit rating before approval of a consumer loan. At the same time, if the bank is not recognized to be financially sound, social security is under a threat. That happens when the loan debtors and customers are not reliable anymore, i.e. they are not financially sound. That situation has its pre-history which indicates that they have managed to hide their unfavourable conditions from the bank or provide the distorted information violating the confidence level in a society and increasing risks.

Modern enterprises spend considerable finances to provide information security and search for the innovative principles of the efficient use of reliable technologies. Thus, it is necessary to rely on the technologies minimizing risks or making them impossible relative to the object of cooperation. Any enterprise owner is interested in the fact that the amounts, invoiced from the consumers for goods, works, or services sold on credit, will be paid back timely as in case of current receivables within the 12-month period from the balance sheet date, which then will change into the long-term ones to be paid back after the 12-month 
period, it will not change into the uncollectible receivables with the expired period of positive age or there will be the confidence in its not being paid back.

It is possible to evaluate efficiency of any enterprise using certain conditions connected with the collective responsibility, e.g. modern individual transportation service relies on the collective responsibility and social assessment and rust. Certain inspection at the conventionally nationwide level analyzes the operation in terms of specific list of the objective factors: reliability of the transportation vehicle mechanisms, driver's license of the required category, available first-aid kit and fire extinguisher, medical condition of a driver. Success of Uber is based on the drivers' rating and reputation built on the opinions of each customer who has made use of the driver's transportation services.

Consequently, it is quite possible that the enterprises which have decided to use cryptoassets (cryptocurrency) for their settlements should be rated to determine the reliability and confidence that the receivables will be repaid within the established deadlines. Thus, the distributed data register makes it possible to assure each customer that the obtained data are reliable. All the system participants keep such a register, and it is updated automatically to the latest version if someone makes any amendments in it; each participant guarantees the information reliability in that register. Such a register is actually the accounting book of the events in the digital environment. Once the information is recorded, it cannot be changed or destroyed.

Ukraine should study the practice of those countries which has been applying actively the blockchain technology. For instance, in Georgia that technology is used at the National Agency of Public Registry. That technology allows receiving official records concerning the required real estate asset. Blockchain helps considerably carry out the tax control procedures. In particular, main problem in the PRC is the optimization of tax legislation and tax evasion. Thus, the Chinese government has charged the internet-provider Tencent (Chinese officers are going to collect taxes by means of blockchain) with the task to develop the blockchain-based "smart tax" to identify tax evasions. Owing to that innovation, the network of digital payment for invoices, consignment bills, and tax invoices has become transparent. That has made it possible to eliminate "unreliable" accounts.

Besides, the Revenue Service of Florida has announced the cooperation with the processing service BitPay to start accepting taxes and fees for property, driving licenses, identity cards, vehicle plate numbers and other documents in Bitcoin and BitcoinCash cryptocurrencies (Dubinina, 2018).

National enterprises perform constant control of the amount and critical level of the receivables in general as well as in terms of each debtor in particular; however, insufficient attention is paid to their repayment period. Due to that fact, enterprises form considerable amount of the doubtful debt having further effect on the financial situation of an enterprise (Cherchata et al. 2020). Consequently, if enterprises provide integrated blockchain-based accounting system before their operations with another company, there will be the possibility to get the initial information about that company. Secondly, while using cryptocurrency as the payment instrument, the system will rate automatically each enterprise representing the information concerning previous practice of the similar operations. Basing on that, Enterprise $\mathrm{A}$ and $\mathrm{B}$ will estimate the event immediately and define the procedure of their interactions: either product shipment before payment or advanced payment with the following product shipment (Wang, 2019).

Each transaction between the enterprises is formed in one data block which is encrypted and which has encrypted copy of the data block from the previous one. After that, the blocks form a chain of actions united with the help of cryptographic signatures. Information in the blocks has time marks of the transactioning distributed and protected against the fraud. First 
of all, that helps obtain certain level of data and transaction protection as there is no possibility to change the data in one of the blocks unnoticeably since the system checks the data and monitors their actuality all the time. According to that, the blockchain acts automatically as an accountant since it monitors financial operations in the real-time mode preventing the system from errors or intentional manipulations with the data. Such a technology widens significantly the accounting capabilities and increases social confidence in the accounting information. Following improvement of the settlements between enterprises involving cryptoassets in the blockchain environment is proposed (Fig.1).

\begin{tabular}{|c|c|c|}
\hline \multicolumn{3}{|c|}{$\begin{array}{l}\text { Financial solvency of enterprises A and B; } \\
\text { Type of payment instruments; } \\
\text { Financial accounts; } \\
\text { Tax consequences for enterprises A and B from the conducted transactions; } \\
\text { Formation of the information concerning the prime cost (production and actual "B"); } \\
\text { Primary accounting document }\end{array}$} \\
\hline $\begin{array}{l}\text { Enterprise A and B } \\
\text { Determination of the } \\
\text { event (advanced } \\
\text { payment or shipment) }\end{array}$ & $\begin{array}{l}\text { Each party has access to } \\
\text { its own data block }\end{array}$ & $\begin{array}{c}\text { Development of a chain } \\
\text { of blocks for that } \\
\text { operations }\end{array}$ \\
\hline \multicolumn{3}{|c|}{$\begin{array}{c}\text { PRIMARY DOCUMENTS } \\
\text { Invoices, tax invoices, sales invoices, credit tickets, bank statements }\end{array}$} \\
\hline \multicolumn{3}{|c|}{$\begin{array}{l}\text { REFERENCE DATA } \\
\text { Client books, inventory, finished products, financial accounts }\end{array}$} \\
\hline \multicolumn{3}{|c|}{$\begin{array}{l}\text { INTERMEDIATE INFORMATION } \\
\text { Maturity date, delivery period, liability of the parties, value and means of payment }\end{array}$} \\
\hline \multirow[t]{3}{*}{$\begin{array}{l}\text { Transaction is shown in } \\
\text { the network where new } \\
\text { data block is formed }\end{array}$} & \multirow[t]{3}{*}{$\begin{array}{c}\text { Blocks are formed and } \\
\text { sent to each participant } \\
\text { of the system }\end{array}$} & $\begin{array}{l}\text { End of transaction and } \\
\text { reporting of data }\end{array}$ \\
\hline & & 25 \\
\hline & & $\begin{array}{l}\text { Data accounting } \\
\text { REPORTING }\end{array}$ \\
\hline
\end{tabular}

Figure 1 Blockchain-based accounting

National enterprises perform constant control of the amount and critical level of the receivables in general as well as in terms of each debtor in particular; however, insufficient attention is paid to their repayment period. Due to that fact, enterprises form considerable amount of the doubtful debt having further effect on the financial situation of an enterprise (Cherchata et al. 2020; Ievdokymov et al., 2020). Consequently, if enterprises provide integrated blockchain-based accounting system before their operations with another company, 
there will be the possibility to get the initial information about that company. Secondly, while using cryptocurrency as the payment instrument, the system will rate automatically each enterprise representing the information concerning previous practice of the similar operations. Basing on that, Enterprise A and B will estimate the event immediately and define the procedure of their interactions: either product shipment before payment or advanced payment with the following product shipment (Wang, 2019).

First of all, method of the operation conducting and type of payment instrument to be used are rather important conditions (DellaSeta et al. 2020; Andrusiv et al. 2020). Thus, it is required to make a managerial solution basing on the following conditions:

- Initial price for product $\mathrm{P}_{1}$;

- Whether the initial price includes transportation costs;

- What monetary means will be used for settlement;

- What rating (in terms of what "event") the enterprise has;

- Index of financial solvency and position of accounts receivable (payable).

For instance, $\mathrm{P}_{1}=\mathrm{UAH} 2,400 ; \mathrm{P}_{11}=\mathrm{USD} 100 ; \mathrm{P}_{111}=0.3$ bch or 0.01 btc (as of 27.01.2020).

Shares of expense item $A=30 \%$ - without the transportation costs;

Shares of expense item $\mathrm{B}=40 \%$ - including the transportation costs;

Shares of expense item $\mathrm{C}=25 \%$ - a customer will pick up the products.

Consider a matrix of consequences for index $\mathrm{A}$ in more detail

$$
\mathrm{Q}_{1}=\left[\begin{array}{lll}
30 & 40 & 25 \\
40 & 25 & 40 \\
30 & 35 & 35
\end{array}\right]
$$

Assume that the settlements will involve traditional monetary means in the national currency $-\mathrm{q}_{1}-0.4$; monetary means in some foreign currency $-\mathrm{q}_{2}-0.5$; and in some cryptocurrency $-\mathrm{q}_{3}-0.1$.

In this context, probability level is $\mathrm{q}_{1}+\mathrm{q}_{2}+\mathrm{q}_{3}=1$

First of all, find the expected income from the set $\mathrm{Q}_{1}$.

$\mathrm{q}_{1}=34.5$

$$
\left\{\begin{array}{l}
30 * 0.4+40 * 0.5+25 * 0.1 \\
40 * 0.4+25 * 0.5+40 * 0.1 \\
30 * 0.4+35 * 0.5+35 * 0.1
\end{array}\right\}
$$

$\mathrm{q}_{2}=32.5$

$\mathrm{q}_{3}=33$

According to the criteria of maximum expected income, it is expedient to choose first solution $\mathrm{q}_{1}=34.5$

Determine risks of using specific monetary means.

$$
\sqrt{(\mathrm{q} 1-\mathrm{q} 1) \wedge 2 * \mathrm{P} 1}
$$

$\mathrm{R}_{1}=97$

$\mathrm{R}_{2}=5$

$\mathrm{R}_{3}=82$ 
According to the criterion of minimal risk, it is necessary to choose $\mathrm{R}_{1}$. Thus, if the operation of finished goods shipment is on the advanced-payment basis and a consumer picks up the purchase, then the settlement should be in the national currency. However, if there arises the account receivables and we are not sure in the consumer's reliability and financial solvency, it is reasonable to choose the cryptocurrency variant. Since the product price in UAH depends on the USD exchange rate and the expected bitcoin cash value depends on the bitcoin, it is expedient to choose risk $\mathrm{R}_{3}$, as the rating is applied only for the enterprises which use cryptoassets (Li et al., 2019).

\section{CONCLUSIONS}

The research has paid great attention to the possibility of practical application of blockchain technology with the integration in the current automated accounting systems. As it has been mentioned, technological progress and rapid innovative development require considerable changes and flexible response from the companies in different industries. A problem of confidentiality and reliability of the information storage is becoming more critical; that is the reason why the implementation of blockchain technology is one of the variants to guarantee data transparency. Having studied the examples of successful implementation of blockchain technology in different spheres of activity, it has been emphasized that the development of similar system is rather expedient and promising trend. Implementation of such innovative technologies and blockchain may favour more efficient company management. Further promising studies may involve use of digital currency on the payment markets and further development of the accounting system at an enterprise.

\section{REFERENCES}

[1] Andrusiv, U., Kinash, I., Cherchata, A., Polyanska, A., Dzoba, O., Tarasova, T \& Lysak, H. (2020). Experience and prospects of innovation development venture capital financing. Management Science Letters, 10(4), 781-788. doi: 10.5267/j.ms1.2019.10.019

[2] Adamik, F., \& Kosta, S. (2019). Smartexchange: Decentralised trustless cryptocurrency exchange doi:10.1007/978-3-030-04849-5_32

[3] Ak, E., \& Canberk, B. (2019). BCDN: A proof of concept model for blockchain-aided CDN orchestration and routing. Computer Networks, 161, 162-171. doi:10.1016/j.comnet.2019.06.018

[4] Bashynska, I., Malanchuk, M., Zhuravel, O., \& Olinichenko, K. (2019). Smart solutions: Risk management of crypto-assets and blockchain technology. International Journal of Civil Engineering and Technology, 10(2), 1121-1131.

[5] Cherchata, A., Popovychenko, I., Andrusiv, U., Simkiv, L., Kliukha, O \& Horai, O. (2020). A methodology for analysis and assessment of business processes of Ukrainian enterprises. Management Science Letters, 10(3), 631-640. doi: 10.5267/j.msl.2019.9.016

[6] Chinese officials plan to collect taxes through blockchain. URL: goo.gl/hLcuJu.

[7] Choi, J. J., \& Ozkan, B. (2019). Innovation and disruption: Industry practices and conceptual bases doi:10.1108/S1569-376720190000020003

[8] Della Seta, M., Morellec, E., \& Zucchi, F. (2020). Short-term debt and incentives for risktaking. Journal of Financial Economics, doi:10.1016/j.jfineco.2019.07.008

[9] Dubinina M., Syrtseva S., Buganov O. \& Tusova N. (2018). Time chain technology as a means of accounting transformation. Modern economics. Vol. 12. P. 75-80.

[10] Edmonds, M., Miller, T., \& Savage, A. (2019). Accounts receivable: An audit simulation. Journal of Accounting Education, 47, 75-92. doi:10.1016/j.jaccedu.2019.04.001 
[11] Filipova N. (2018). "Blockchain - An Opportunity for Developing New Business Models." Business Management, D. A. Tsenov Academy of Economics, Svishtov, Bulgaria, issue 2 Year 20, 75-92.

[12] Heister, S., \& Yuthas, K. (2020). The blockchain and how it can influence conceptions of the self. Technology in Society, 60 doi:10.1016/j.techsoc.2019.101218

[13] Ievdokymov, V., Lehenchuk, S., Zakharov, D., Andrusiv, U., Usatenko, O \& Kovalenko, L. (2020). Social capital measurement based on "The value explorer" method. Management Science Letters, 10(6), 1161-1168. doi: 10.5267/j.msl.2019.12.002

[14] Kim, C. Y., \& Lee, K. (2018). Risk management to cryptocurrency exchange and investors: Guidelines to prevent potential threats. Paper presented at the 2018 International Conferene on Platform Technology and Service, PlatCon 2018, doi:0.1109/PlatCon.2018.8472760

[15] Kurgan, N. V. (2019). Evolution and prospects of automation of accounting accounting and submission of Ukraine's enterprises of automation of submission. Electronic scientific professional publication. P. 249.

[16] Li, J., Yuan, Y., \& Wang, F. -. (2019). A novel GSP auction mechanism for ranking bitcoin transactions in blockchain mining. Decision Support Systems, 124 doi:10.1016/j.dss.2019.113094

[17] López-Cabarcos, M. Á., Pérez-Pico, A. M., Piñeiro-Chousa, J., \& Šević, A. (2020). Bitcoin volatility, stock market and investor sentiment. are they connected? Finance Research Letters, doi:10.1016/j.frl.2019.101399

[18] Melnychenko O. \& Hartinger R. (2016) The role of blockchain technology in accounting and auditing. Wspótpraca Europejska. Vol. 7. No. 14. - P. 9

[19] Morabito, V. (2017). Business innovation through blockchain: The B3 perspective. Business innovation through blockchain: The B0RW1S34RfeSDcfkexd09rT431RW1S34RfeSDcfkexd09rT4 perspective (pp. 1-173) doi:10.1007/978-3-319-48478-5

[20] Onuklu, A. (2019). Research on blockchain: A descriptive survey of the literature doi:10.1108/S1569-376720190000020015

[21] Osmyatchenko V. O. \& Oliynyk V. S. (2018). The state and prospects of accounting development in the context of changing technological ways. Economic Bulletin. Series: Finance, Accounting, Taxation. №. 2, pp. 131-138.

[22] Pushkar M. \& Semanyuk V. (2018) "The relevance of developing a modern accounting paradigm." Institute for Accounting, Control and Analysis in a Globalization 1-2: p. 7-20.

[23] Skvortsova, T. A., Mosienko, T. A., Ulezko, A. Y., Nikolaev, A. V., \& Arzumanyan, A. A. (2020). Development of digitization in contractual relations doi:10.1007/978-3-03029586-8_117

[24] Swan, M. (2016). Blockchain temporality: Smart contract time specifiability with blocktime doi:10.1007/978-3-319-42019-6_12

[25] Tang, Y., Xiong, J., Becerril-Arreola, R., \& Iyer, L. (2019). Blockchain ethics research: A conceptual model. Paper presented at the SIGMIS-CPR 2019 - Proceedings of the 2019 Computers and People Research Conference, 43-49. doi:10.1145/3322385.3322397

[26] Tarasova, T., Usatenko, O., Makurin, A., Ivanenko, V. \& Cherchata, A. (2020). Accounting and features of mathematical modeling of the system to forecast crypto currency exchange rate. Accounting, 6(3), DOI: 10.5267/j.ac.2020.1.003

[27] The Florida Tax Service will accept bitcoins and bitcoin cash. URL: http://goo.gl/tZGLPU. 
Blockchain Technology as an Organization of Accounting and Management in a Modern Enterprise

[28] The Georgia Public Register began to use Blockchain technology. URL: goo.gl/wCS53y

[29] Wang, M., Han, M., \& Huang, W. (2019). Debt and stock price crash risk in weak information environment. Finance Research Letters, doi:10.1016/j.frl.2019.05.004

[30] Manisha Valera, Parth Patel and Shruti Chettiar, (2018) An Avant-Garde Approach of Blockchain in Big Data Analytics, International Journal of Computer Engineering and Technology, 9(6), pp. (115)-(120)

[31] Deepika Sachdev, (2019) Enabling Data Democracy in Supply Chain using Blockchain and IoT, Journal of Management, 6(1), pp. 66-83.

[32] Ragh Satya Sai Medida, (2020) Scope of Blockchain Technology inthe Retail Industry, International Journal of Computer Engineering and Technology, 11(3), pp. 26-30. 